\title{
Role Of Public Prosecutors In Corruption Crime Prosecution
}

\author{
Agung Nugroho Santoso*) and Sri Kusriyah ${ }^{* *}$ \\ *)Civil Servant, E-mail : ag_blackmantaray@yahoo.co.id \\ ${ }^{* *}$ F Faculty of Law Universitas Islam Sultan Agung
}

\begin{abstract}
The aims of this study are as follows: To identify and analyze the role of the Public Prosecutor in prosecuting defendants for corruption. To find out and analyze the efforts that will be made by the Public Prosecutor if the decision handed down by the Judge of the Corruption Court is not in accordance with the demands of the Public Prosecutor. The approach method used in this study is a sociological juridical research method. The specifications in this study are analytical descriptive. Based on the results of this study, the role of the Public Prosecutor in Prosecuting Defendants of Criminal Acts of Corruption, namely the public prosecutor in carrying out prosecutions for criminal acts of corruption has been sufficient to prove the fulfillment of the elements of criminal acts of corruption that were violated by the defendant as a result of the actions committed. Starting from the investigation, prosecution, legal action which then if it already has permanent legal force, the prosecutor's office as in making charges against criminal acts of corruption is regulated in Article 137, Article 139 and Article 143 of the Criminal Procedure Code as well as Act No. 16 of 2004 concerning the Attorney General's Office of the Republic of Indonesia. Indonesia, thus giving confidence to the judge that the defendant's actions had violated the criminal provisions he was charged. Examination of the Cassation Level for Legal Interests (Article 259 of the Criminal Procedure Code). Review of Court Decisions that have Permanent Legal Force (Article 263 of the Criminal Procedure Code).
\end{abstract}

Keywords: Role; Public Prosecutor; Corruption; Crime.

\section{Introduction}

Indonesia is a democratic legal state based on Pancasila and the 1945 Constitution of the Republic of Indonesia, upholds human rights, and guarantees all citizens based on their position in law and government and are obliged to uphold the law and government with no exceptions. ${ }^{1}$

Article 1 Paragraph (3) of the 1945 Constitution of the Republic of Indonesia states that the Indonesian state is a state of law, the affirmation of this constitutional provision means that all aspects of life in society, state and government must always be based on law. To realize a state of law, one of which requires legal instruments that are used to regulate balance and justice in all fields of national and state life through laws and regulations. ${ }^{2}$

Law enforcement is closely related to legal regulations and law enforcement institutions, if the first concerns the laws and regulations, while the second concerns the driving institutions, such as the Indonesian Police, the Indonesian Attorney General's Office, courts and prisons, and the Corruption Eradication Commission

${ }^{1}$ Evi Hartanti, 2005, Tindak Pidana Korupsi, ed. I; Sinar Grafika, Jakarta, p. 1.

${ }^{2}$ Sri Endah Wahyuningsih, 2018, Model Pengembangan Asas Hukum Pidana Dalam KUHP Berbasis Nilai-nilai Ketuhanan Yang Maha Esa, Fastindo, Semarang, p 3-4. 
$(\mathrm{KPK}) .^{3}$ Law enforcement is an integral part of legal development, while law development itself is an integral component of national development. ${ }^{4}$

Corruption in Indonesia is widespread in society. Its development continues to increase from year to year. The increase in uncontrolled corruption will bring disaster, not only to the life of the national economy but also to the life of the nation and state in general. Corruption is a violation of social rights and economic rights of the community. Corruption has become an extraordinary crime. Likewise, eradication efforts can no longer be carried out in an ordinary way, but are required in an extraordinary way. Furthermore, it is proven that there is a link between corruption and other forms of crime, especially organized crime (terrorism, trafficking in persons, smuggling of illegal migrants and others) and economic crimes (money laundering).

The crime of corruption is one part of the special criminal law in addition to having certain specifications that are different from the special criminal law, such as deviations from the procedural law and when viewed from the material regulated, the crime of corruption is directly or indirectly intended to minimize leakage and irregularities in the country's finances and economy. By anticipating these deviations as early and as minimally as possible, it is hoped that the wheels of the economy and development can be carried out properly so that gradually it will have an impact on increasing development and the welfare of society in general. ${ }^{5}$

One of the institutions that are given the authority to enforce the law in an effort to eradicate corruption is the Prosecutor's Office. The role of the prosecutor in the criminal justice system is very central because the prosecutor is the institution that determines whether a person should be examined by the court or not. The prosecutor also determines whether a person will be sentenced or not through the quality of the indictment and the demands he makes.

The Prosecutor's Office of the Republic of Indonesia is a state institution that carries out state power, especially in the field of prosecution. As an authorized body in law enforcement and justice, the Prosecutor's Office is led by the Attorney General who is elected by and responsible to the President. The Attorney General's Office, the High Prosecutor's Office, and the District Attorney's Office are state powers, especially in the field of prosecution, all of which are a unified whole that cannot be separated.

Referring to Act No. 16 of 2004 which replaced Act No. 5 of 1991 concerning the Indonesian Attorney General's Office, the Prosecutor's Office as one of the law enforcement agencies is required to play a greater role in upholding the rule of law, protecting public interests, upholding human rights, and eradicating Corruption, Collusion and Nepotism (KKN). In the new Prosecutor's Law, the Indonesian Prosecutor's Office as a state institution exercising state power in the field of

\footnotetext{
${ }^{3}$ Rozi, M. M,. 2017, Peranan advokat sebagai penegak hukum dalam sistem Peradilan pidana dikaji menurut undang-undang Nomor 18 tahun 2003 tentang advokat. Jurnal Hukum Mimbar Justitia, $1(2)$, p. 628-647.

${ }^{4}$ Nugroho, H. 2008. Paradigma Penegakan Hukum Indonesia Dalam Era Global. Jurnal Hukum Pro Justitia, 26(4), p. 236-243

5 Lilik Mulyadi, 2000, Tindak Pidana Korupsi (Tinjauan Khusus Terhadap Proses Penyidikan, Penuntutan, Peradilan Serta Upaya Hukumnya Menurut Undang-undang Nomor 31 Tahun 1999), Citra Aditya Bakti, Bandung, p. 1, 2.
} 
prosecution must carry out its functions, duties and authorities independently, regardless of the influence of government power and the influence of other powers. ${ }^{6}$

In carrying out its duties and authorities, the Attorney General's Office is led by the Attorney General who oversees 6 (six) Junior Attorney Generals, 1 (one) Head of the Indonesian Attorney's Education and Training Agency and 32 Heads of High Prosecutor's Office in each province. UU no. 16 of 2004 concerning the Prosecutor's Office of the Republic of Indonesia also indicates that the Prosecutor's Office is in a central position with a strategic role in strengthening national resilience. Because the Prosecutor's Office is on the axis and becomes a filter between the investigation process and the examination process at trial or prosecution as well as implementing court decisions and decisions. Thus, the Prosecutor's Office is the controller of the case process (Dominus Litis), because only the Prosecutor's Office can determine whether a case can be submitted to the Court or not based on valid evidence according to the Criminal Procedure Code. The Prosecutor's Office is also the only agency implementing criminal decisions (executive ambtenaar). The Prosecutor as the executor of this authority is given the authority as a Public Prosecutor and carries out court decisions, and other powers based on the Act.

The aims of this study are as follows: To identify and analyze the role of the Public Prosecutor in prosecuting defendants for corruption. To find out and analyze the efforts that will be made by the Public Prosecutor if the decision handed down by the Judge of the Corruption Court is not in accordance with the demands of the Public Prosecutor.

\section{Research Methods}

The approach method used in this research is a sociological juridical method (Sociological Research) which emphasizes the practice in the field related to the legal aspects or legislation in force regarding the object of research.7 In accordance with the approach method used, namely sociological juridical, the specifications in this study are analytical descriptive. The data collection method in this study is primary data obtained from field studies. And secondary data obtained from literature study. The data were analyzed qualitatively using law enforcement theory and justice theory.

\section{Results and Discussion}

\subsection{Role of Public Prosecutor in Corruption Crime Prosecution}

Corruption has occurred in all lines of activity in State Institutions and Institutions, and has even been categorized as an extraordinary crime. This condition has a negative impact on the implementation of sustainable national development to improve people's welfare, because the state budget funds, both central and regional, which can be used to build public service infrastructure such

\footnotetext{
${ }^{6}$ Article 2 paragraph 2 of Act No. 16 of 2004 concerning the Prosecutor's Office of the Republic of Indonesia.

${ }^{7}$ Amuruddin and Zainal Asikin, 2003, Pengantar Metode Penelitian Hukum, Raja Grafindo Persada, Jakarta, p. 21
} 
as health services, education, social assistance in the form of clothing and food, are reduced due to acts of corruption. The United Nations pays attention to the incidence and impact of acts of corruption in the form of a convention (United Nation Convention Against Corruption) which is agreed upon by the countries participating in the convention. Prevention and prosecution through law enforcement must be carried out comprehensively so that the implementation of law enforcement is effective. Law enforcement for acts of corruption that are currently occurring should be carried out starting from planning the implementation of regulations and implementing regulations, so that the implementation and implementation of laws and regulations in the context of law enforcement becomes effective. To find out law enforcement for corruption, especially those that are detrimental to the State, an analysis and evaluation of Act No. 31 of 1999 as amended by Act No. 2 of 2001 is carried out. The conclusions of the analysis and evaluation are as input and consideration in formulating legislation in the future. ${ }^{8}$

Pre-trial is an institution that was born from the idea of carrying out supervisory actions against law enforcement officers (Police, Prosecutors and Judges) so that in carrying out their authority they do not abuse their authority, because internal supervision is not enough within the legal apparatus itself, but cross supervision is also needed between fellow law enforcement officers. ${ }^{9}$

The examination of criminal acts of corruption is carried out at the Corruption Court, which is a special court within the general court environment and the only court that has the authority to adjudicate a case of a criminal act of corruption whose prosecution is carried out by the public prosecutor. ${ }^{10}$ The procedural law used in examining criminal acts of corruption in court is basically carried out in accordance with Act No. 8 of 1981 concerning the Criminal Procedure Code (KUHAP), unless otherwise stipulated in the Corruption Crimes Act.

Law enforcers involved in eradicating corruption are investigators, public prosecutors, and judges. The final determinant in eradicating corruption is the judge. However, the judge cannot act actively outside the context of the case being brought to trial by the public prosecutor. Meanwhile, the Prosecutor is the Prosecutor who is active in conducting the investigation, investigation and prosecution process. It is no exaggeration to say that the Prosecutor's Office is one of the determinants of success in eradicating corruption. Vice versa, if until now the eradication of corruption has failed, has not been successful or at least is considered not optimal, then the one that is considered a failure, has not been successful or is considered not optimal, one of which is the Prosecutor's Office. ${ }^{11}$

The role of the Public Prosecutor in Prosecuting Defendants of Criminal Acts of Corruption, namely the public prosecutor in carrying out prosecutions for criminal acts of corruption, has been sufficient to prove the fulfillment of the elements of

\footnotetext{
${ }^{8}$ Hulman Siregar, Rumusan Pidana Dan Pemidanaan Tindak pidana Korupsi Yang Merugikan Keuangan Negara Serta Permasalaan Dalam Penerapannya, Jurnal Daulat Hukum Vol. 1. No. 1. March, 2018 ISSN: 2614-560X, Unissula

${ }^{9}$ Dodik Hartono, Maryanto, Djauhari, Peranan Dan Fungsi Praperadilan Dalam Penegakan Hukum Pidana Di Polda Jateng, Jurnal Daulat Hukum Vol. 1. No. 1 March, 2018 ISSN: 2614-560X, Unissula 10 https://acch.kpk.go.id Corruption Court, accessed 16 June 2021

${ }^{11}$ Salahudin Luthfie, 2011, Kewenangan Kejaksaan Dalam Penyidikan Tindak Pidana Korupsi, Tesis Magister Ilmu Hukum Universitas Indonesia, p. 2.
} 
criminal acts of corruption that were violated by the defendant as a result of the actions committed. Starting from the investigation, prosecution, legal action which then if it already has permanent legal force, the prosecutor's office as in making charges against criminal acts of corruption is regulated in Article 137, Article 139 and Article 143 of the Criminal Procedure Code as well as Act No. 16 of 2004 concerning the Attorney General's Office of the Republic of Indonesia. Indonesia, thus giving confidence to the judge that the defendant's actions had violated the criminal provisions he was charged.

\subsection{Efforts will be made by Public Prosecutor if Judge's decision is not in accordance with the demands}

Handling corruption crimes carried out by the Prosecutor's Office has been one of the main missions and is the main task that must be succeeded in line with the demands for reform in the field of law enforcement in Indonesia. Various policies and instructions from the leadership of the Prosecutor's Office in an effort to encourage and increase the intensity of handling cases of criminal acts of corruption by all levels of the Prosecutor's Office throughout Indonesia are continuously issued in line with the development of the quantity and quality of the modus operandi of corruption cases in Indonesia.

Corruption in Indonesia has penetrated into all lines of people's lives, it is even said to be entrenched in society. Widespread corruption, which is carried out systematically. Not only is it detrimental to state finances, corruption has also violated social and economic rights, which are classified as extraordinary crimes. In fact, in a large number of cases, state losses and their modus operandi are increasing from year to year. ${ }^{12}$ Corruption has become a kind of phenomenon of everyday life in Indonesia. The various institutions, actions, and judgments against them are fostered in a series of major actions that are usually under the title "fighting corruption". ${ }^{13}$

The development of corruption in Indonesia is still relatively high, while its eradication is still very slow. Romli Atmasasmita stated that corruption in Indonesia is a virus that has spread throughout the government since the eradication of the eradication in the 1960s. Furthermore, it is said that corruption is also related to power because the ruler can abuse his power for personal, family and cronies interests. ${ }^{14}$

Corruption which is categorized as an extraordinary crime is not only a disaster for the national economy, but also a violation of the social and economic

\footnotetext{
${ }^{12}$ Suwono, Jawade Hafidz, Upside of Evidence by Public Prosecutor in The Case Corruption by Act No. 31 of 1999 jo. Act No. 20 of 2001 on Combating Crime of Corruption, Jurnal Daulat Hukum Volume 1 Issue 3 September 2018 ISSN: 2614-560X, Unissula

${ }^{13}$ Cipto Dwi Leksana and Rakhmat Bowo Suharto, Implementation of Cooperation Agreement Between the Ministry of Internal Affairs, Police, Attorney General Office (Ago) in Handling and Crime Of Corruption in Indonesia, Jurnal Daulat Hukum Volume 2 Issue 1, March 2019 ISSN: 2614-560X, Unissula

14 Romli Atmasasmita, 2004, Sekitar Masalah Korupsi, Aspek Nasional dan Aspek Internasional, Mandar Maju, Bandung, p. 1.
} 
rights of the people. The police as part of the legal system, have a very important role in law enforcement of anti-corruption laws. ${ }^{15}$

Efforts that will be made by the Public Prosecutor if the decision handed down by the Judge of the Corruption Court is not in accordance with the demands of the Public Prosecutor, namely a. Examination of the Cassation Level for Legal Interests (Article 259 of the Criminal Procedure Code). In the interest of law, all decisions that have obtained permanent legal force from courts other than the Supreme Court may be submitted 1 (one) time by the Attorney General and the cassation decision for legal purposes may not harm the interested parties. b. Review of Court Decisions that have Permanent Legal Force (Article 263 of the Criminal Procedure Code). Against court decisions that have obtained permanent legal force, except decisions that are acquitted or free from all lawsuits.

\section{Closing}

The role of the Public Prosecutor in Prosecuting Defendants of Criminal Acts of Corruption, namely the public prosecutor in carrying out prosecutions for criminal acts of corruption, has been sufficient to prove the fulfillment of the elements of corruption crimes that were violated by the defendant due to the actions committed. Starting from the investigation, prosecution, legal action which then if it already has permanent legal force, the prosecutor's office as in making charges against criminal acts of corruption is regulated in Article 137, Article 139 and Article 143 of the Criminal Procedure Code as well as Act No. 16 of 2004 concerning the Attorney General's Office of the Republic of Indonesia. Indonesia, thus giving confidence to the judge that the defendant's actions had violated the criminal provisions he was charged with.

Efforts will be made by the Public Prosecutor if the decision handed down by the Corruption Court Judge is not in accordance with the demands of the Public Prosecutor, namely Examination of the Cassation Level for Legal Interests (Article 259 of the Criminal Procedure Code). Review of Court Decisions that have Permanent Legal Force (Article 263 of the Criminal Procedure Code).

It is hoped that the prosecutor can carry out his duties and authorities properly, especially in prosecution, carrying out judges' determinations and supervising decisions, especially on parole so that the convicts can obtain their rights and the sense of community justice is fulfilled.

\section{References}

\section{Journal}

[1] Cipto Dwi Leksana and Rakhmat Bowo Suharto, Implementation of Cooperation Agreement Between the Ministry of Internal Affairs, Police, Attorney General

\footnotetext{
${ }^{15}$ Muhamad Riyadi Putra and Gunarto, Analysis Of Handling Practices On Corruption Crime By Police (Case Study In Special Criminal Investigation Police Directorate Of Central Java), Jurnal Daulat Hukum Volume 2 Issue 2, June 2019 ISSN: 2614-560X, Unissula
} 
Office (Ago) in Handling and Crime Of Corruption in Indonesia, Jurnal Daulat Hukum Volume 2 Issue 1, March 2019 ISSN: 2614-560X, Unissula

[2] Dodik Hartono, Maryanto, Djauhari, Peranan Dan Fungsi Praperadilan Dalam Penegakan Hukum Pidana Di Polda Jateng, Jurnal Daulat Hukum Vol. 1. No. 1 March, 2018 ISSN: 2614-560X, Unissula

[3] Hulman Siregar, Rumusan Pidana Dan Pemidanaan Tindak pidana Korupsi Yang Merugikan Keuangan Negara Serta Permasalaan Dalam Penerapannya, Jurnal Daulat Hukum Vol. 1. No. 1 March, 2018 ISSN: 2614-560X, Unissula

[4] Muhamad Riyadi Putra and Gunarto, Analysis Of Handling Practices On Corruption Crime By Police (Case Study In Special Criminal Investigation Police Directorate Of Central Java), Jurnal Daulat Hukum Volume 2 Issue 2, June 2019 ISSN: 2614-560X, Unissula

[5] Nugroho, H. 2008. Paradigma Penegakan Hukum Indonesia Dalam Era Global. Jurnal Hukum Pro Justitia, 26 (4)

[6] Rozi, M. M,. 2017, Peranan advokat sebagai penegak hukum dalam sistem Peradilan pidana dikaji menurut undang-undang Nomor 18 tahun 2003 tentang advokat. Jurnal Hukum Mimbar Justitia, 1(2)

[7] Suwono, Jawade Hafidz, Upside of Evidence by Public Prosecutor in The Case Corruption by Act No. 31 of 1999 jo. Act No. 20 of 2001 on Combating Crime of Corruption, Jurnal Daulat Hukum Volume 1 Issue 3 September 2018 ISSN: 2614-560X, Unissula

\section{Books}

[1] Amuruddin and Zainal Asikin, 2003, Pengantar Metode Penelitian Hukum, Raja Grafindo Persada, Jakarta

[2] Burhan Ashshofa, 2007, Metode Penelitian. Media Press, Semarang

[3] Evi Hartanti, 2005, Tindak Pidana Korupsi, ed. I; Sinar Grafika, Jakarta

[4] Lilik Mulyadi, 2000, Tindak Pidana Korupsi (Tinjauan Khusus Terhadap Proses Penyidikan, Penuntutan, Peradilan Serta Upaya Hukumnya Menurut Undangundang Nomor 31 Tahun 1999), Citra Aditya Bakti, Bandung,

[5] Romli Atmasasmita, 2004, Sekitar Masalah Korupsi, Aspek Nasional dan Aspek Internasional, Mandar Maju, Bandung

[6] Salahudin Luthfie, 2011, Kewenangan Kejaksaan Dalam Penyidikan Tindak Pidana Korupsi, Tesis Magister Ilmu Hukum Universitas Indonesia

[7] Sri Endah Wahyuningsih, 2018, Model Pengembangan Asas Hukum Pidana Dalam KUHP Berbasis Nilai-nilai Ketuhanan Yang Maha Esa, Fastindo, Semarang

\section{Internet}

https://acch.kpk.go.id pengadilan Tipikor, accessed on 16 June 2021 